\title{
Evaluation of the Coagulating Potential of the Crude Extract from the Barbatimão Bark for the Treatment of Dairy Effluents
}

\author{
Vanuzia Rodrigues Fernandes Ferreira'1, Josefina Aparecida de Souza1, \\ Maria das Graças Cardoso ${ }^{*}$, Luiz Gustavo de Lima Guimarães ${ }^{2}$, Rafaela Magalhães Brandão1, \\ Rafaela Vieira Souza1, Luana Isac Soares' ${ }^{1}$, Jéssica Oliveira e Nogueira1, \\ Francielli D’Carlos Cravo', David Lee Nelson ${ }^{3}$ \\ ${ }^{1}$ Department of Chemistry, Federal University of Lavras, Lavras, Brazil \\ ${ }^{2}$ Federal University of São João Del Rei, São João Del Rei, Brasil \\ ${ }^{3}$ Pro-Reitoria de Pesquisa e Pós-Graduação, Federal University of Vales de Jequitinhonha and Mucuri, Diamantina, Brazil \\ Email: *mcardoso@dqi.ufla.br
}

How to cite this paper: Ferreira, V.R.F., de Souza, J.A., das Graças Cardoso, M., de Lima Guimarães, L.G., Brandão, R.M., Souza, R.V., Soares, L.I., Nogueira, J.O., Cravo, F.D. and Nelson, D.L. (2016) Evaluation of the Coagulating Potential of the Crude Extract from the Barbatimão Bark for the Treatment of Dairy Effluents. American Journal of Plant Sciences, 7, 1685-1692. http://dx.doi.org/10.4236/ajps.2016.713159

Received: July 27, 2016

Accepted: September 3, 2016

Published: September 6, 2016

Copyright $\odot 2016$ by authors and Scientific Research Publishing Inc. This work is licensed under the Creative Commons Attribution International License (CC BY 4.0). http://creativecommons.org/licenses/by/4.0/ (c) (i) Open Access

\begin{abstract}
The coagulating potential of the crude extract from the barbatimão bark for the treatment of dairy effluent was assessed and compared with industrial coagulants such as aluminum sulfate (inorganic coagulant), the crude extract of black wattle bark (used in the manufacture of natural organic coagulants), and gallic acid (the main constituent of condensed tannins). The aqueous extract of barbatimão was obtained by refluxing for $12 \mathrm{~h}$, and the black wattle was provided by a producer of natural coagulants. The determinations of total phenolic compounds and tannins in the extracts were performed by the Folin-Ciocalteu method and precipitation with casein, respectively. The treatment of the effluent with coagulant was performed by the Jar-Test. After testing, the effluent was evaluated for turbidity, total solids, and biochemical oxygen demand (BOD). A higher content of phenolic compounds (19.81\% $\mathrm{mg}$ of gallic acid/g extract) was observed in the barbatimão extract than in the black wattle extract (14.24\% $\mathrm{mg}$ of gallic acid/g extract). However, the extracts contained the same amount of tannins, $13.95 \%$ for the barbatimão extract and $12.89 \%$ for the black wattle extract. A $63 \%$, reduction in BOD was observed for the effluent treated with barbatimão extract, $35 \%$ for the black wattle extract, $58 \%$ for gallic acid and $60.59 \%$ for the treatment with aluminum sulfate. Treatment with gallic acid caused a $98 \%$ reduction in the turbidity of the effluent; with aluminum sulfate, a $97 \%$ reduction was obtained; with barbatimão extract, $96 \%$, and with black wattle extract,
\end{abstract}


93\%. The barbatimão extract was shown to be a potential coagulant for dairy effluents.

\section{Keywords}

Stryphnodendron adstringens, Acacia mearnsii, Tannins

\section{Introduction}

Dairy industries produce effluents that have high levels of organic matter, consisting mainly of milk and its by-products. These effluents are rich in proteins, lipids and carbohydrates [1]. The disposal of this type of untreated wastewater into bodies of water decreases the amount of dissolved oxygen because it increases the concentration of organic matter in the receiving body. It triggers the self-purification process of rivers or lakes, which may cause the death of aquatic species and the proliferation of waterborne diseases [2].

The importance of wastewater treatment is recognized throughout the world. In Brazil, it is regulated by agencies such as the CONAMA (National Environment Council), which sets standards for the disposal of waste [3]. In view of the current legislation, the treatment of wastewater is accomplished in three stages: preliminary, primary and secondary treatment.

The preliminary treatment removes coarse solids. The primary treatment removes suspended solids, and its action can be increased by a chemical process that uses coagulants to promote the reduction in the amount of the organic matter. The secondary treatment removes residual organic material, usually with the addition of a biological stage [2].

In the primary treatment, the suspended or particulate organic matter is removed by gravity [2]. However, simple decanting cannot eliminate all the colloidal impurities [4], so the addition of chemical agents is necessary. This addition favors the neutralization of the repulsive forces between the particles in suspension and causes agglomeration and sedimentation. This process is termed coagulation and is accomplished by means of electrically charged chemical compounds that bind or adsorb on the surfaces of particles present in colloidal suspension.

Inorganic salts are widely used in coagulation because they have electrical charges that are opposite those of the colloids [4]. Aluminum and iron salts are among those used. Their use increases the concern about the quality of such treatments because these metals are undesirable in the treated water and the sludge obtained at the end of the process. They are heavy metals, and aluminum has undesirable effects [5].

Tannins are macromolecules derived from secondary plant metabolism [6]. Tannins are organic coagulants that have been developed for cleaning treatments because they are biodegradable coagulants obtained from renewable sources. These natural coagulants assist in the removal of organic matter; they are able to form insoluble complexes 
in water with nitrogenous compounds, including proteins [6].

One of the species that have been studied for the production of these coagulants is the black wattle (Acacia mearnsii), native to Australia. It is cultivated in Brazil in the state of Rio Grande do Sul for the commercial production of natural coagulants. However, its spread is hampered by the high degree of seed dormancy [7]. There are Brazilian species, such as the barbatimão (Stryphnodendron adstringens), that contain high levels of tannins, especially in the bark of their trunks. This species is native and endemic to the Brazilian cerrado and is known by the community for its high medicinal value [8]. It is a two to eight-foot-tall, deciduous [9], evergreen tree [10].

The study of the barbatimão is of fundamental importance because it can lead to results that will increase the economic value of the species. This plant has been inordinately exploited by the rural community and pharmaceutical industries [8], and its conservation through sustainable management is important. This study can lend support for that conservation. This study evaluated the potential of the crude extract of barbatimão bark as a coagulant in the treatment of dairy effluents and compared its clotting effect with those of the coagulants used commercially, such as the black wattle extract and aluminum sulfate.

\section{Material and Methods}

\subsection{Collection and Processing of Plant Material}

Plant material (bark) from the barbatimão was collected from five trees located close to one another. The collection was performed in the southeast of Minas Gerais in the municipality of Itumirim, in the morning in February 2013.

The plant utilized was identified as Stryphnodendron adstringens (barbatimão), a member of the Fabaceae family. A voucher specimen was prepared and is deposited in the Herbarium of the Biology Department of the Federal University of Lavras (UFLA) under number 27475 .

The processing of the plant material occurred on the day of collection. The bark was placed in a ventilated oven with mechanical circulation of the air (FANEM 320-SE) at $30^{\circ} \mathrm{C}$ for about seven days in the Organic Chemistry Laboratory-Essential Oils of the Chemistry Department of UFLA. After drying, the material was ground in a grinder (Weq, $132 \mathrm{M}$ 1076) in the Department of Forest Science of the UFLA using a sieve with a $1.5 \mathrm{~mm}$ aperture (12 to $14 \mathrm{mesh}$ ).

\subsection{Obtaining Crude Extracts of Barbatimão and Black Wattle}

The aqueous extract of the bark from barbatimão (EACB) was obtained by refluxing $86.52 \mathrm{~g}$ of dried and ground material in a round bottom flask $(1 \mathrm{~L})$ with $500 \mathrm{~mL}$ of distilled water. The material was left at a slow reflux for 12 hours, counting from the beginning of boiling. After the material was filtered through a Buchner funnel, the filtrate was freeze-dried (Labconco, Freezone 4.5) for five days in the Biochemistry Laboratory of the Chemistry Department of UFLA, The solid residue was stored in a brown bottle at approximately $4^{\circ} \mathrm{C}$. The crude extract of black wattle was provided by an industry 
(ECAN) that manufactures natural organic coagulants.

\subsection{Determination of Total Phenols and Tannins}

The total phenolic contents in black wattle and barbatimão extracts were determined by the Folin-Ciocalteu method, and the tannin content was determined by precipitation with casein [11]. The determinations were performed in the Organic Chemistry Laboratory of the Chemistry Department of UFLA.

\subsection{Collection and Evaluation of Dairy Effluent}

The raw wastewater was provided by a dairy near Lavras, MG, Brazil. This wastewater was evaluated soon after collection with respect to turbidity, employing a turbidimeter (TB microprocessor 1000, TECNOPON); $\mathrm{pH}$; and the biochemical oxygen demand (BOD), which was obtained by measuring the dissolved oxygen (DO day) and the oxygen (DO Day 5) consumed by microorganisms in the degradation of organic matter during the 5-day interval [2].

\subsection{Dairy Effluent Decantation Assay}

The treatments were performed at the Organic Chemistry Laboratory of the Chemistry Department of UFLA using the "jar test" (Micro controlled JT-203, MILAN) equipment. All the analyses were performed in duplicate.

The treatments were performed using $1 \mathrm{~L}$ of the raw effluent in an acid medium. The $\mathrm{pH}$ of the raw wastewater was adjusted with sulfuric acid to about 4.5 , which is the isoelectric point of casein [12].

The first treatment consisted only of acidification of the crude effluent. In the second treatment, $1.5 \mathrm{~g}$ of barbatimão extract was added, and $1.5 \mathrm{~g}$ of black wattle extract was added in the third treatment.

The amounts of barbatimão and black wattle extracts used in the treatments were previously determined in settling tests, in which various $0.5 \mathrm{~g}$ portions of extracts were added. The optimum dose was considered to be that in which the greatest reduction in turbidity and BOD was observed.

In the fourth treatment, $0.200 \mathrm{~g}$ of gallic acid (used as a model) was added because barbatimão extracts are rich in hydrolysable black wattle tannin and release gallic acid units [6]. The amount of gallic acid used in the treatment of the effluent was equivalent to the amount of tannin present in the barbatimão and black wattle extracts.

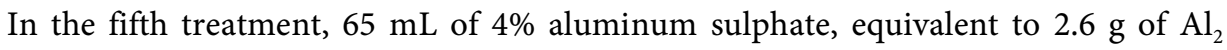
$\left(\mathrm{SO}_{4}\right)_{3}$, was used. This dosage was determined from the turbidity of the effluent, which is a common practice in treatment plants.

After the addition of the coagulant, the system was stirred for 1 minute at $67 \mathrm{~g}$. The determination of settled solids was performed in inmhoff cones for 1 hour [3]. In natura effluent was used as the blank for the analysis. After decanting, the effluents were evaluated for turbidity, using a turbidimeter (TB microprocessor 1000, TECNOPON), $\mathrm{pH}$ using $\mathrm{pH}$ strips and BOD. 


\subsection{Determination of DBO}

The biochemical oxygen demand (BOD) was performed by measuring dissolved oxygen consumed (DO) by microorganisms in the organic matter degradation process during the 5-day interval [2]. Therefore, two measurements of dissolved oxygen were conducted, one at the time of sampling (first day) and one on the fifth day of incubation of the sample at $23^{\circ} \mathrm{C} \pm 1^{\circ} \mathrm{C}$ in BOD (SOLAB, SL-200). The BOD was calculated by the following relationship.

$$
\mathrm{BOD}=\mathrm{DO}_{\text {fifth day }}-\mathrm{DO}_{\text {first day }}
$$

\subsection{Statistical Analysis}

The experimental design was completely randomized. The average for total phenolic compounds and tannins were compared by the $\mathrm{F}$ test at $5 \%$ probability. As for turbidity, settled solids and BOD were compared by the Scott-Knott test at $5 \%$ probability. The tests were performed using the Sisvar [13] statistical program.

\section{Results and Discussion}

\subsection{Determination of Total Phenolic Compounds and Tannins}

The crude extract from barbatimão had a strong red color, characteristic of condensed tannins [6]. After lyophilization of the extract, a fine, reddish brown powder was obtained (Figure 1). The total phenolic compounds and tannins present in the barbatimão and black wattle extracts are presented in Table 1.

Literature data demonstrate that extracts of black wattle and the barbatimã barks contain around $20 \%$ to $30 \%$ of tannins, respectively. There is a variation in chemical

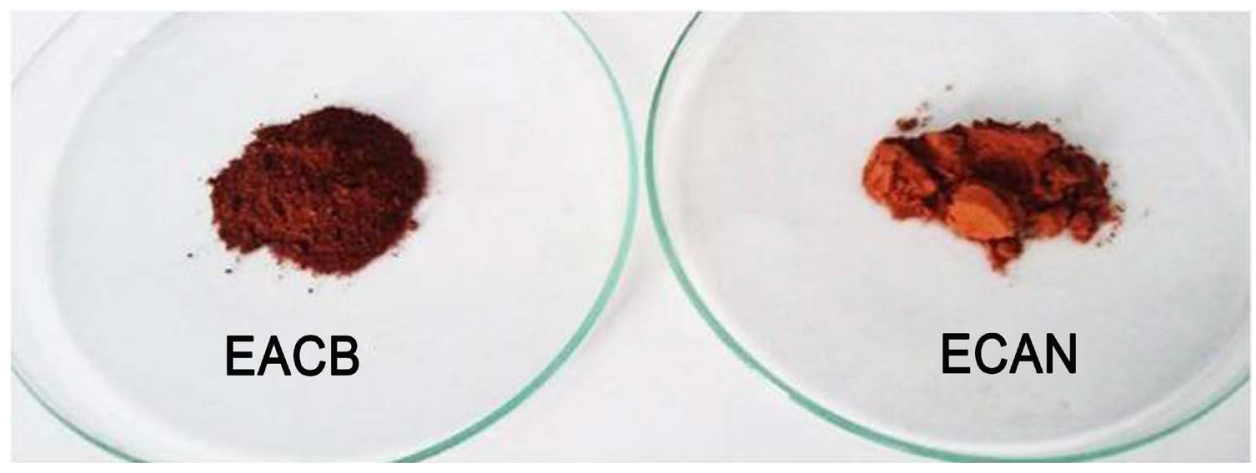

Figure 1. Crude extract of barbatimão (EACB) and black wattle (ECAN).

Table 1. Contents of total phenolic compounds and tannins in the extracts of barbatimão and black wattle barks.

\begin{tabular}{ccc}
\hline Extract & Total phenols (mg of gallic acid/g of extract) & Tannins (mg of gallic acid/g of extract) \\
\hline Barbatimão & $19.81 \pm 0.53 \mathrm{a}$ & $13.95 \pm 0.37 \mathrm{a}$ \\
Black wattle & $14.24 \pm 0.35 \mathrm{~b}$ & $12.89 \pm 0.29 \mathrm{a}$ \\
\hline
\end{tabular}

The means followed by the same letter in a column do not differ according to the F Test at a $5 \%$ level of probability. 
composition according to species [8] [11] [15]. Statistically, the barbatimão extract contained more phenolic compounds than the black wattle extract, but the barbatimão and black wattle extracts contained the same amount of tannins, so it was possible to establish a relationship between tannin content and the coagulant action of the extracts.

\subsection{Decantation Assay}

The results for effluent treatment are presented in Table 2. Assays for determining the dosage of extract are important because there is an optimum ratio between proteins and tannins that provides the maximum precipitation [14] and the greatest reduction in the organic matter in the effluent.

The largest reductions in turbidity were observed for the treatments with ECAN, gallic acid and aluminum sulfate. These coagulants decreased the turbidity of the effluent from 1348 to $30 \mathrm{NTU}$, representing approximately $97 \%$ reduction. Turbidity measures the transparency of the sample via the light scattering caused by particles or suspended solids. Thus, the reduction in turbidity of the effluent is associated with coagulation because the impurities are removed from the effluent in the form of solids (sludge). Theoretically, the turbidity, BOD and solids variables are directly related.

The most efficient coagulants in reducing BOD were barbatimão bark extract, gallic acid and aluminum sulfate, which reduced the BOD from 1256 to 463, 525 and 495 $\mathrm{mg} \cdot \mathrm{L}^{-1}$, respectively. The barbatimão bark extract is not among the coagulants that caused the greatest reduction in turbidity. A reduction from 1348 to 96 NTU was observed with this extract, corresponding to a $92.87 \%$ reduction. However, the greatest amount of precipitation ( $200 \mathrm{~mL}$ of sludge from $1 \mathrm{~L}$ of effluent) was observed with this extract.

Despite the fact that the greatest reduction in turbidity was observed with the black wattle bark extract and the second greatest quantity of sludge $\left(285 \mathrm{~mL} \cdot \mathrm{L}^{-1}\right)$ was obtained with this extract, it was not as effective as the others in reducing the BOD. A 35\% reduction in organic matter from 1256 to $816 \mathrm{mg} \cdot \mathrm{L}^{-1}$ was observed.

The acidification of the effluent caused a $91 \%$ reduction in turbidity and a $40 \%$ re-

Table 2. Effect of different anticoagulants on some physical and chemical properties of the effluent.

\begin{tabular}{cccccc}
\hline Coagulant & Dose & $\mathrm{pH}$ & Turbidity NTU & Sólids mL.L $\mathrm{L}^{-1}$ & BOD mg.L $\mathrm{L}^{-1}$ \\
\hline Blank & - & 11 & $1348 \mathrm{a}$ & $0 \mathrm{f}$ & $1256 \mathrm{a}$ \\
$\mathrm{H}_{2} \mathrm{SO}_{4}$ & $1.00 \mathrm{~mL}$ & 4.50 & $122 \mathrm{~b}$ & $20 \mathrm{e}$ & $754 \mathrm{~b}$ \\
$\mathrm{EACB}$ & $1.50 \mathrm{~g}$ & 4.50 & $96 \mathrm{~b}$ & $200 \mathrm{a}$ & $463 \mathrm{c}$ \\
ECAN & $1.50 \mathrm{~g}$ & 4.50 & $42 \mathrm{c}$ & $185 \mathrm{~b}$ & $816 \mathrm{~b}$ \\
$\mathrm{Gallic} \mathrm{acid}$ & $0.20 \mathrm{~g}$ & 4.50 & $30 \mathrm{c}$ & $72 \mathrm{~d}$ & $525 \mathrm{c}$ \\
$\mathrm{Al}_{2}\left(\mathrm{SO}_{4}\right)_{3}$ & $2.60 \mathrm{~g}$ & 4.50 & $52 \mathrm{c}$ & $95 \mathrm{c}$ & $495 \mathrm{c}$ \\
\hline
\end{tabular}

"NTU-Turbidity unit. The means followed by the same letter in the columns do not differ by the Scott-Knott test at a $5 \%$ level of probability. 
duction in BOD. This observation can be attributed to the fact that $\mathrm{pH} 4.5$ is the isoelectric point of casein, the principal milk protein [12]. At this $\mathrm{pH}$, the surface electric charge of casein is null, and there is no repulsion between the colloidal particles, so clumping and settling of these particles results so that there is a reduction in turbidity and BOD of the effluent.

Despite the fact that good results in decreasing turbidity and BOD were obtained by acidification of the medium, the addition of coagulants potentiates that decrease because the dairy effluent is composed of other proteins and impurities in addition to casein and these proteins are also in a colloidal state.

Colloidal particles are stabilized by the electrical double layer formed on the surface of the colloids, which prevents approach and agglomeration [15] [16]. These impurities generally have a negative surface charge and are destabilized by positively charged electrolytes such as acids and inorganic salts such as aluminum sulfate [4]. The barbatimão and black wattle extracts precipitate proteins because they are rich in tannins, but these tannins also act as electrolytes because tannins are phenolic compounds and behave as weak acids. These molecules are stable even when electrically charged because of resonance that is provided by aromatic groups.

Although the barbatimão and black wattle extracts have almost the same amount of tannins (13.95\% and $12.89 \%$, respectively), better results in the precipitation of organic matter were obtained with the barbatimão extract. This fact can be attributed to the greater amount of phenolic compounds and the presence of other secondary metabolites characteristic of the species that assist in coagulation.

The reductions in BOD obtained with the barbatimão extract and with aluminum sulfate were higher than that provided by the legislation, which established a minimum of $60 \%$ reduction in BOD effluent as a criterium for disposal [3]. The reduction in BOD observed with gallic acid, which was used as a model for the extracts, was similar to that observed with the barbatimão extract, $58 \%$ and $63 \%$, respectively. This fact suggests that the coagulating action of the extract is mostly controlled by hydrolysable tannins present in the extract. This relationship was not observed for the black wattle extract, as this reduced the BOD by only $35 \%$.

\section{Conclusion}

The crude extract of barbatimão has a potential as a coagulant for the treatment of dairy effluent because its use leads to a reduction in biochemical oxygen demand in accordance with the law and it contributed to the decrease in turbidity of the effluent after treatment.

\section{Acknowledgements}

The authors thank the Fundação de Amparo à Pesquisa do Estado de Minas Gerais (FAPEMIG), the Conselho Nacional de Desenvolvimento Científico e Tecnológico (CNPq), the and Coordenação de Aperfeiçoamento de Pessoal de Nível Superior (CAPES) the for financial support, a scholarship and a PVNS fellowship (D.L. Nelson). 


\section{References}

[1] Santos, A.M., Silva, S.R., Carvalho, S.H.V. and Soletti, J.I. (2009) Tratamento de Efluentes Lácteos através de Coagulação Química e Sedimentação. VIII Congresso Brasileiro de Engenharia Química em Iniciação Científica. Uberlândia, Minas Gerais, Brasil, 27-30. http://www.cobeqic2009.feq.ufu.br/uploads/media/80813851.pdf

[2] Sperling, M.V. (2005) Introdução à Qualidade das Águas e ao Tratamento de Esgoto: Princípios do tratamento biológico de águas residuárias. 3rd Edition, Belo Horizonte.

[3] Ministério do Meio Ambiente (2011) Resolução CONAMA No. 430. http://www.mma.gov.br/port/conama/res/res11/propresol_lanceflue_30e31mar11.pdf

[4] Piantá, C.A.V. (2008) Emprego de Coagulantes Orgânicos Naturais Como Alternativa ao Uso do Sulfato de Alumínio no Tratamento de Água. Trabalho de diplomação. Universidade Federal do Rio Grande do Sul, Porto Alegre.

[5] Dias, A.C.Vi., Dezotti, M. and Massarani, G. (2005) Estudo Comparativo entre os Efeitos do Tanino e de um Coagulante Convencional sobre a Filtração Rápida usada no Tratamento de Água para Abastecimento. 23 Congresso Brasileiro de Engenharia Sanitária e Ambiental. Campo Grande, 18-23 de Setembro de 2005.

http://www.bvsde.paho.org/bvsacd/abes23/I-066.pdf

[6] Simões, C.M.O., et al. (2007) Farmacognosia: Da planta ao medicamento. UFRGS, Porto Alegre, $1102 \mathrm{p}$.

[7] Roversi, T., Mattei, V., Siveira, J.P. and Falck, G.L. (2002) Superação da Dormência em Sementes de Acácia negra (Acácia mearnsii Willd). Revista Brasileira de Agrociência, 8, 161-163.

[8] Meira, M.R., Cabacinha, C.D., Figueiredo, L.S. and Martins, E.R. (2013) Barbatimão: Ecologia, Produção de Taninos e Potencial Sócio Econômico na Região Norte Mineira. Universidade Federal de Minas Gerais-UFMG.

[9] Borges Filho, H.C. and Felfili, J.M. (2003) Avaliação dos níveis de extrativismo da casca de barbatimão Stryphnodendron adstringens (Mart.)Coville no Distrito Federal, Brasil. Revista Árvore, Viçosa, 27, 735-745.

[10] Lorenzi, H. (2000) Árvores brasileiras: Manual de identificação e cultivo de plantas arbóreas nativas do Brasil. Instituto Plantarum, Nova Odessa, 370 p.

[11] Monteiro, J.M., Neto, E.M.F.L., Amorim, E.L.C., Strattmann, R.R., Araújo, E.L. and Albuquerque, U.P. (2005) Teor de Taninos em Três Espécies Medicinais Arbóreas Simpátricas da Caatinga. Sociedade de investigações florestais, R. Arvore viçosa-MG, 29, 999-1005.

[12] Perry, K.S.P. (2004) Queijos: Aspectos químicos, bioquímicos e microbiológicos. Química Nova, 27.

[13] Ferreira, D.F. (2011) Sisvar: A computerstatistic alanalysis system. Ciência e Agrotecnologia, Lavras, 35, 1039-1042.

[14] Santos, S.C. and Mello, J.C.P. (2004) Taninos. In: Simões, C.M.O., Schenkel, E.P., et al., Eds., Farmacognosia: Da Planta ao Medicamento, 5th Edition, UFSC, Porto Alegre, 631633.

[15] Pansera, M.R., Atti-Santos, A.C., Serafini, L.A. and Cassel, E. (2001) Supercritical Extraction of Tannin with Co-Solvents. IV Encontro Brasileiro de Fluidos Supercríticos em Salvador-Bahia, 42.

[16] Skoog, D.A., West, D.M., Holler, F.J. and Crouch, S.R. (2011) Fundamentos de Química Analítica. Cengage Learning, São Paulo. 
Submit or recommend next manuscript to SCIRP and we will provide best service for you:

Accepting pre-submission inquiries through Email, Facebook, LinkedIn, Twitter, etc. A wide selection of journals (inclusive of 9 subjects, more than 200 journals)

Providing 24-hour high-quality service

User-friendly online submission system

Fair and swift peer-review system

Efficient typesetting and proofreading procedure

Display of the result of downloads and visits, as well as the number of cited articles

Maximum dissemination of your research work

Submit your manuscript at: http://papersubmission.scirp.org/ 